\title{
Policy Document on Work Based Learning in Higher Quality Accredited Institutions
}

\author{
Christo Ananth ${ }^{1}$ \\ ${ }^{1}$ College of Engineering, AMA International University, Kingdom of Bahrain
}

\begin{abstract}
This Policy Document incorporate Work-Based Learning in its program offering with the goal for understudies to build up their abilities, capacities, demeanors, proficient traits, and hard working attitudes that add to their employability and deep rooted learning. The strategy archive and systems examined diagram the procedures in helping understudies over the span of their Work-Based Learning exercises. They additionally characterize the jobs and duty of the Dean, Program Head, Practicum Adviser, and Practicum Supervisor as a team with the Head of Placement, Linkage and Alumni Office
\end{abstract}

Keywords- Course Intended Learning Outcomes, Higher Quality Accredited Institutions, Practicum, Placement, Linkage and Alumni Office, Work Based Learning.

\section{INTRODUCTION}

The Work Based-Learning is a fundamental piece of all undergrad programs. It incorporates exercises that furnish understudies with different chances to apply their insight and aptitudes from study hall to working environment situations managed by Work BasedLearning linkage accomplices. The expected learning results of Work Based-Learning are evaluated and credited as a major aspect of the understudies learning program. Work-Based Learning is a work place-based, surveyed, and credited learning exercises of the University program intelligent of the suitable planned learning results. Practicum Student is an understudy tried out the Practicum course who gets hands-on involvement and creates aptitudes pertinent to Work Based-Learning manager accomplices' needs through Work Based-Learning openings. Practicum Adviser is a full-time staff of the recognized school in the college who will legitimately execute the program via completing the obligations and duties indicated in this. Practicum Supervisor is an assigned agent of Work Based-Learning boss accomplice who is allocated to oversee and administer the on location usage of Work Based-Learning exercises where the Practicum Student is on Work Based-Learning drenching. Work Based-Learning Employer-Partner is any private or government business, medicinal, designing, or processing organization, industry, establishment, or association which gives Work Based-Learning chances to Work Based-Learning understudies. Appraisal is the assessment of an understudy's exhibition or accomplishment of the Work BasedLearning destinations in the acknowledgment of the Work Based-Learning's Course Intended Learning Outcomes. Arrangement is the whole procedure of doing Work Based-Learning exercises by understudies, Work Based-Learning counsel, coach, director and Work BasedLearning boss accomplices.

\section{RESPONSIBILITIES IN WORK BASED LEARNING}

The Dean guarantees that the Work Based-Learning proposed learning results add to the general points of the individual understudies projects; and affirms Work Based-Learning structures and systems used to screen understudies' advancement. The Department Head assigns understudies' Practicum Advisers, manages Practicum Advisers in the accommodation of the understudies' Work Based-Learning execution assessment; and endorses the timetable and direct organization visits. Head of Placement, Linkage and Alumni Office in a joint effort with Practicum Advisers helps understudies in distinguishing 
Christo Ananth et al., International Journal of Advanced Research in Innovative Discoveries in Engineering and Applications[IJARIDEA]

Vol.3, Issue 6, 27 December 2018, pg. 13-15

and assigning Work Based-Learning arrangements in the event that they have not picked one; underwrites understudies to their recognized Work Based-Learning business accomplices; encourages the direct of the Work Based-Learning Orientation Seminar; gives Work BasedLearning structures and systems to screen understudies' advancement; screens the exercises of Practicum Students through real visits at any rate once per week for each checking period; gathers and procedures the consequences of Employer Survey that permit Work BasedLearning manager accomplices to evaluate and offer criticism to understudies' presentation in their working environment, including the overview for the understudy's achievement of the Student Outcomes/Program Intended Learning Outcomes ; behaviors vocation course, profession fairs, and related exercises to help understudies' profession improvement and satisfaction of their expert achievement; and keeps and updates records/information of data of Work Based-Learning boss accomplices, for example, (an) organization profile; (b) name, contact number, and email address of Work Based-Learning boss who will be in charge of administering/supporting/observing the Work Based-Learning encounters; and reinforce associations with Work Based-Learning boss accomplices.

Practicum Adviser arranges the understudies on Work Based-Learning approaches and system and other Work Based-Learning related issues as a team with the Placement, Linkage and Alumni Office Head; reacts to understudy inquiries/concerns identified with Work Based-Learning background and evaluation methods; and gets ready, submits, and encode understudies' imprint each reviewing period. guarantees that Practicum Students are given a genuine work by Practicum Supervisors that are significant to their scholarly planning; counsels with the Practicum director on understudy's exhibition; monitors the understudies' advancement and ensures that prerequisites for the stamping time frames are submitted on schedule; assesses the presentation of the understudies in meeting with Practicum administrator and gives the understudies mark. Practicum Supervisor: characterizes the sorts and nature of Work Based-Learning openings accessible in the organization, business, foundation, or association; surveys the Practicum Students' advancement and execution during the Work Based-Learning period; gives organization, industry, establishment, or association data to Practicum Students; empowers the Practicum Students to increase reasonable, sheltered, better than average, and favorable Work BasedLearning encounters and openings; and helps Practicum Students in the improvement and culmination of Work Based-Learning Accomplishment Report by giving fitting appraisal and other appropriate data. Practicum Student goes to the Work Based-Learning direction/conference sessions with Practicum Adviser on Work Based-Learning arrangements, methodology, and Work Based-Learning related exercises at any rate once every week; performs doled out task(s) quickly and palatably by connecting completely in Work Based-Learning procedures to accomplish the planned learning results; educates Practicum Supervisor and Practicum Adviser, of any worries which will influence, in one way or the other, the attractive accomplishment of the Work Based learning results; uses the Work Based-Learning structures to archive and to track the revealing day's action, issues experienced, arrangements offered or potentially actualized, and so forth ; lives with the Work Based-Learning business accomplices' guidelines and approaches; keeps up privacy of any touchy data concerning the exchanges in the Work Based-Learning condition; illuminates ahead of time the Practicum Supervisor of any nonattendances or lateness from the booked work hours and counsels him/her for any worries identified with Work Based-Learning; adjusts with the Work Based-Learning manager accomplice's way of life, techniques, administration and programmes; and submits prerequisites to Practicum Adviser. 


\section{PROCEDURES AND ASSESSMENT FOR WORK BASED LEARNING}

Practicum understudy submits application letter with connections to the Placement, Linkage and Alumni Office Head; Placement, Linkage and Alumni Office Head gets ready underwriting to Work Based-Learning manager linkage accomplice; Upon acknowledgment by Work Based-Learning business accomplice, the Practicum Student achieves the required structures; goes to the pre-organization direction led; and starts the on location Work BasedLearning exercises. Practicum understudies' exhibition is surveyed dependent on the accompanying: assessment of skills by Practicum manager; assessment of execution achievement by Practicum boss submitted Practicum Accomplishment Report, including the Anti-Plagiarism Report, Practicum Students' class execution as evaluated by the Practicum Adviser. Quality Records incorporate Updated List/Database of Employers/Training organizations/Industries/Companies/Organizations, Endorsement Letters to Companies, Training Opportunities' File Record, Competencies Evaluation Form, Performance Evaluation Form and Practicum Accomplishment Report. These Documents are circulated to College Deans' Office, Dean of Student Services, Placement, Linkage and Alumni Office and Quality Assurance and Accreditation Office

\section{IV.. CONCLUSION}

This Policy Document incorporate Work-Based Learning in its program offering with the goal for understudies to build up their abilities, capacities, demeanors, proficient traits, and hard working attitudes that add to their employability and deep rooted learning. The strategy archive and systems examined diagram the procedures in helping understudies over the span of their Work-Based Learning exercises. They additionally characterize the jobs and duty of the Dean, Program Head, Practicum Adviser, and Practicum Supervisor as a team with the Head of Placement, Linkage and Alumni Office

\section{REFERENCES}

[1] Aarkrog, V. (2008-09). Current challenges in the Danish dual VET curricula. VOCAL, Vol. 7, pp. 49-57.

[2] Aggarwal, A., Hofmann, C. and Phiri, A. (2010). A study on informal apprenticeship in Malawi, Employment Sector Employment report No. 9. Geneva, International Labour Organization (ILO).

[3] Ainley, J. (1996). Learning about work in general secondary schools, report for the OECD Thematic review of the Transition from Initial Education to Working Life. Available from www.oecd.org/dataoecd/39/58/1925572.pdf (Accessed 15.10.2012.)

[4] ADB. 2004. Improving Technical Education and Vocational Training: Strategies for Asia. http://www.adb.org/sites/default/files/pub/2004/tech-educ-voc-training.pdf (04 July 2013), Asian Development Bank

[5] Lanka, Available from http://apskills.ilo.org/resources/the-national-qualificationsframework-for-skills-training-reform-in-srilanka (04 July 2013), Asian Development Bank

[6] Bailey, T., Hughes, K., \& Barr, T. (1998). Achieving scale and quality in school-to-work internships: Findings from an employer survey (MDS-902). Berkeley: National Center for Research in Vocational Education, University of California.

[7] Billett, S. (2001). Learning in the Workplace: Strategies for Effective Practice. Crows Nest, NSW, Australia, Allen \& Unwin.

[8] Boud, D., Keogh, R. and Walker, D. (ed.). (1985). Reflection: Turning Experience into Learning. London, Kogan Page.

[9] Brown, A., Bimrose, J., Barnes, S., Kirpal, S., Grønnig, T. and Dæhlen, M. (2010). Changing Patterns of Working, Learning and Career Development Across Europe: Final Report. Warwick, UK, Institute for Employment Research, University of Warwick.

[10] Bundesinstitut für Berufsbildung. (2011). Datenreport zum Berufsbildunsbericht 2011. Available from http://datenreport.bibb.de/Datenreport_2011.pdf (Accessed 15.10.2012.) 